\title{
TRIASSIC ROOTS FROM THE PETRIFIED FOREST NATIONAL PARK
}

\author{
Lyman H. Daugherty \\ Department of Botany, University of Michigan, Ann Arbor, Michigan
}

\begin{abstract}
A B S T R A C T
Daugherty, Lyman H. (U. Michigan, Ann Arbor.) Triassic roots from the Petrified Forest National Park. Amer. Jour. Bot. 50 (8) : 802-805. Illus. 1963.-Araucariorhiza jeae, a new genus and species of Triassic roots, is described. The description includes the root tip with a columella type embryonic region, the secondary roots, the small tertiary roots, and a discussion in regard to the relationship of this form genus.
\end{abstract}

The Following description is based on fossil roots collected by Chief Naturalist Philip F. Van Cleave and on subsequent collections made by Mr. Van Cleave and the writer. The material had eroded from a sandy bentonite of the Chinle formation and a number of specimens were found in a small area at the Itopsidema locality (Daugherty, 1960). This locality is situated approximately $\frac{3}{4}$ mile due north of Agate Bridge in the east central part of Sec. 4, T. 14 N., R. 24 E., within the boundary of the Petrified Forest National Park.2

General features-The fossil roots were discovered within large fragments of a hollow log of Araucarioxylon arizonicum. The $\log$ was approximately $35 \mathrm{~cm}$ in diameter and the entire hollow center was filled with small roots. The secondary roots are ca. 1-4 $\mathrm{mm}$ in diameter and the tertiary roots are ca. $0.4 \mathrm{~mm}$ in diameter. Apparently the log had been in a spongy, water-soaked condition before petrifaction occurred, for small branch roots from the central portion of the $\log$ had also penetrated the wood (Fig. 3). Thin sections show perfect preservation in many of the roots, and, judging from the color, the cell walls had retained a considerable amount of carbon after the impregnation of silica formed chalcedony.

The root TIP-A longitudinal section of the tip of a secondary root $630 \mu$ in diameter, and with excellent cell structure, proved to have a meristematic region common to many extant gymnosperms (Fig. 1). In many, if not all, of the recent conifers the root cap contains a central columella consisting of transversely dividing cells that also can form daughter cells laterally as described by Esau (1960) for Picea and by De Bary (1877) for Juniperus. The fossil root tip contains a distinct columella, and it is assumed cells of the root were formed in the same manner as those being formed by roots with a columella at the present time.

${ }^{1}$ Received for publication January 26, 1963.

The writer is indebted to the Petrified Forest National Park Corporation for expenses incurred on trips to the Petrified Forest, and to the National Science Foundation for financial assistance under grant G-19553, C. A. Arnold project director

2 The Petrified Forest National Monument became a National Park on December 8, 1962.
Tertiary Roots-Small branch roots that were apparently modified for the absorption of water and salts in solution were featured by bulb-like expansions near their tips (Fig. 2, 4). No root caps or root hairs were observed, and epidermal cells of the bulb-like expansions possibly served to carry on absorption. It is not unusual for epidermal cells to function in this manner, for in recent roots having root hairs water absorption may be accomplished by ordinary epidermal cells and is not restricted to the root hairs (Esau, 1960). The stele of the roots is surrounded by an endodermis having Casparian bands and the cortex consists of parenchyma. The stele is diarch, and the cambium was inactive or absent, and, like many small branch roots of extant species, no secondary xylem or phloem was formed.

Secondary roots-The primary xylem of the secondary roots is essentially like that of the tertiary roots. However, all secondary roots developed root caps and a row of cambial initials on both sides of the metaxylem. When the 2 rows of cambial initials were active, 2 cuneate groups of secondary xylem were formed that appear fanshaped in transverse sections (Fig. 7, 8). Often only 1 row of cambial initials became active, and 1 "fan-shaped" structure of secondary xylem was formed (Fig. 6). When a single "fan" developed, the primary xylem was displaced and forced from the center of the root toward the periphery. The secondary xylem is composed of tracheids with 2 rows of alternating bordered pits on their radial walls (Fig. 5), and, in addition to the typical araucarian pitting, a number of tracheids apparently contain resin plugs. Xylem rays, $2-6$ cells high, are uniseriate and consist of procumbent parenchyma cells.

In many roots, the phloem is not well preserved, but occasionally it shows excellent preservation (Fig. 6). Prosenchymatous cells ca. $600 \mu$ long and $25 \mu$ wide are evidently sieve cells although no sieve plates can be observed. Sieve cells of the phloem are approximately square or slightly rectangular in the transverse sections. They are associated with phloem parenchyma and a few isolated sclerotic cells were observed in the periphery of the phloem. 

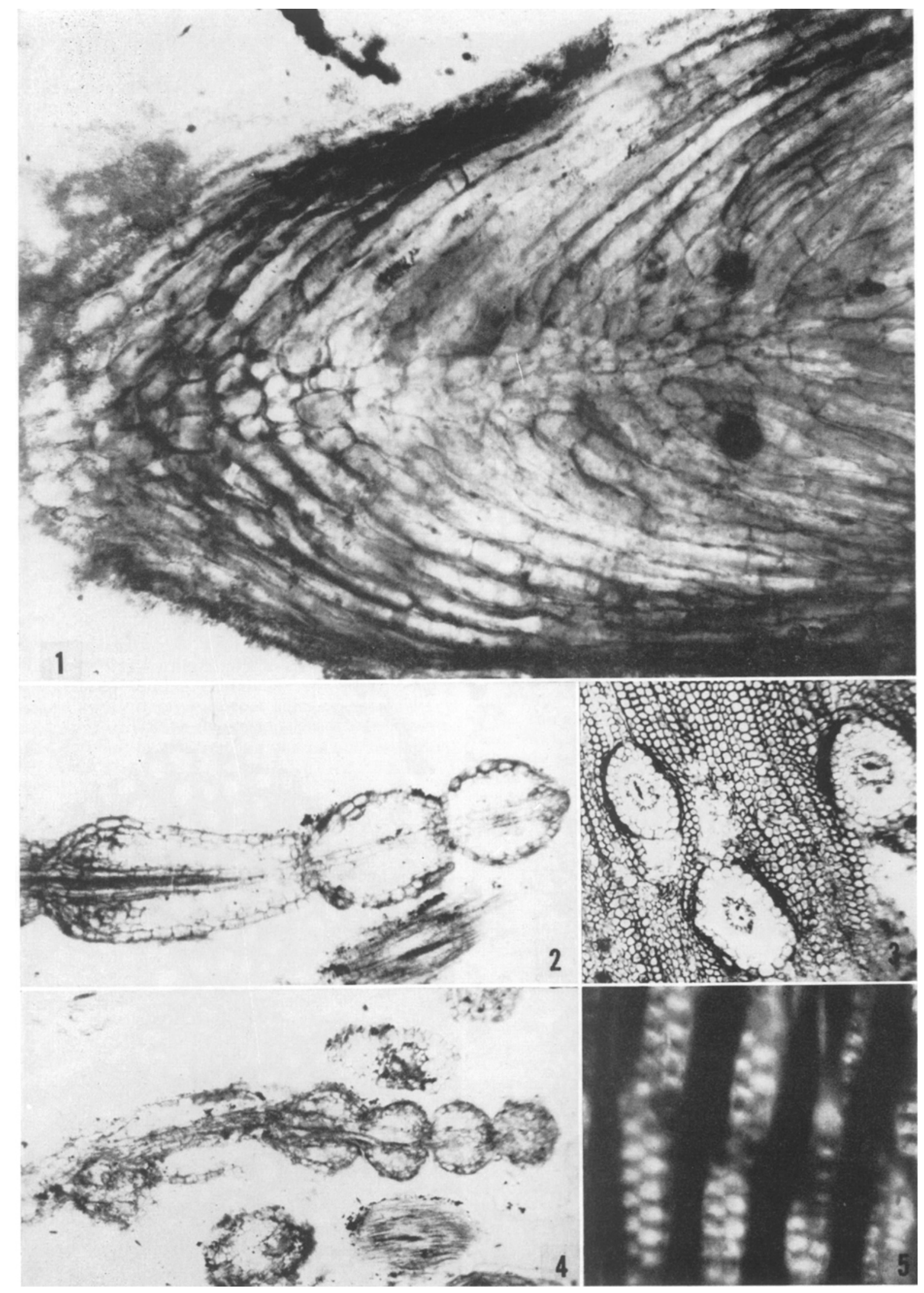

Fig. 1-5.-Fig. 1. Longitudinal section of the tip of a secondary root showing the columella. $\times 208 .-$ Fig. 2. Longitudinal section of the tip of a tertiary root. $\times 56$. - Fig. 3 . Transverse sections of 3 tertiary roots which had penetrated the xylem in a hollow log of Araucarioxylon arizonicum. $\times 47$.-Fig. 4. Jongitudinal section of a tertiary root showing bulb-like expansions. $\times 40$.-Fig. 5 . Radial section of the secondary xylem of a root showing araucarian pitting on al walls of the tracheids. $\times 320$. 


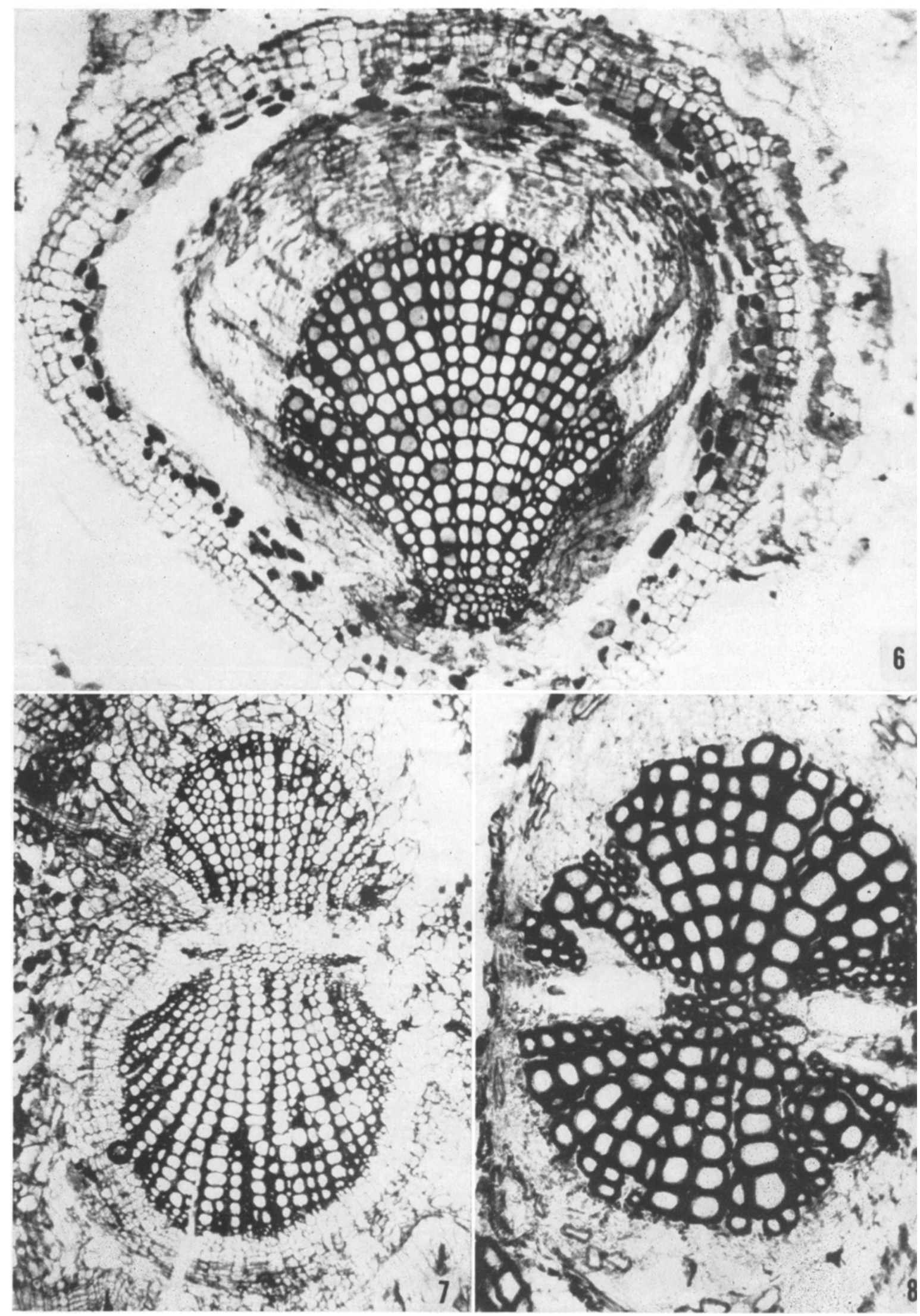

Fig. 6-8.-Fig. 6. Transverse section of a root with a single "fan" of secondury xylem. $\times 70 .-$ Fig. 7. Transverse section of root showing cleavage of the xylem due to cambial activity. $\times 47$. Fir. 8 . Transverse section of the stele of a root having 2 "fans" of secondary xylem. $\times 139$. 
In some cases, the cambial initials had surrounded a single "fan" causing a cleavage of the xylem into 2 masses, with each mass surrounded by a ring of cambium (Fig. 7). A similar phenomenon has been reported for roots of Convolvulus scammonia $\mathrm{L}$. in which the xylem is separated into 4 masses with each group of xylem cells surrounded by a ring of cambial initials (Metcalfe and Chalk, $1950)$.

All secondary roots have well-developed periderm, and phellogen was formed from cells of the pericycle in the same manner as in a majority of recent roots. Following the formation of the phellem, or cork, cells of the epidermis and cortex had sloughed away, but some of the fossil roots show remnants of the cortex still adhering to the outer surface of the phellem (Fig. 6). The phellem consists of several layers of comparatively thinwalled cells with little or no contents and differs from the phelloderm which is composed of cells filled with a dark-brown substance. In some of the older roots, new phellogens had developed from rells of the phloem underneath the original perider'm.

\section{Aravcariorhiza Joat gen. et sp. nov.}

Diagnosis-Roots with diarch stele; secondary xylem consisting of 1 or 2 cuneate groups, tracheids having bordered pits in 2 rows, alternating; root tip containing columella type meristematic region, root cap present, root hairs absent; tertiary roots with bulbous expansions, root cap absent, root hairs absent, Casparian bands in endodermis, cambium absent or inactive.

Age-Upper Triassic, Chinle.

Holotype-roots $\Sigma 1210$ and $\Sigma 1211$.

Holotype in paleobotanical collection of the Petrified Forest National Park and No. 46180 Museum of the University of Michigan, Amn Arbor, Michigan.

Discussion-The form genus Araucariorhiza is proposed for fossil roots with diarch primary xylem and araucarian type pitting on the tracheid walls of the "fan-shaped" masses of secondary xylem. Species of the cordaitalean root genus Amyelon (Scott, 1923) can be distinguished from species of Araucariorhiza by their triarch or tetrarch primary xylem and lack of "fans."

Roots of the recent Dioon edule (South and Compton, 1908) and Cycas revoluta (Life, 1901) have diarch primary xylem but differ from roots of Araucariorhiza in tracheidal pitting and in having nests of sclereids in the cortex. Both Dioon and Cycas have nodules on the roots, but nodules of a similar nature were observed by the writer on secondary roots of Araucaria angustifolia. One nodule with the central cells containing a black substance was found on a root of Araucariorhiza joae. It is possible that the bulb-like expansions at the tips of the tertiary roots (Fig. 2,4) are in- cipient nodules, although the cells show no evidence of an invasion by bacteria, fungi, or bluegreen algae. Stems of both Cycadeoidea and Williamsonia have been found in the Petrified Forest National Park, and very little is known about roots of fossil cycads. Roots of Bennettites (Cycadeoidea) were described by Stopes (1917), but little could be learned from her paper other than that the root was clothed with root hairs.

Secondary roots of Araucaria bidwillii and A. imbricata (Seward and Ford, 1906) have an anatomy essentially like Araucariorhiza joae, and roots of Agathis Moorei (Thomson, 1913) show a remarkable resemblance. Since the fossil roots were found in a hollow $\log$ of Araucarioxylon arizonicum and it is the most common $\log$ in the Petrified Forest National Park (Daugherty, 1941), the evidence is rather convincing that Araucariorhiza joae represents roots of this species. However, roots of Woodworthia arizonica and Dadoxylon chaneyi are unknown, and the possibility that the roots may belong to some plant not yet known for the region must be taken into consideration. Dadoxylon chaneyi is a rare fossil (only 2 specimens have been collected) and Woodworthia arizonica is not common in the horizon of the Chinle formation at the Itopsidema locality. An adventitious root from the fluted base of a log of Schilderia adamanica has a diarch primary xylem, but the secondary xylem forms a cylinder around it and no "fans" are developed. Drawing conclusions from the above, the writer is convinced the roots are those of a member of the Araucarineae and possibly represent roots of Araucarioxylon arizonicum.

\section{LITERATURE CITED}

DAUGHERTY, L. H. 1941. The upper Triassic flora of Arizona. Carnegie Inst. Washington, Publ. 526.

- 1960. Itopsidema, a new genus of the Osmundaceae from the Triassic of Arizona. Amer. Jour. Bot. 47: 771-777.

De BARY, A. 1877. Vergleichend Anatomie der Vegetationorgane der Phanerogamen und Farne. Englemann, Leipzig.

Esau, K. 1960. Anatomy of seed plants. Wiley and Sons, Inc., New York.

Life, A. C. 1901. The tuber-like rootlets of Cycas revoluta. Bot. Gaz. 31: 265-271.

Metcalafe, C. R., AND L. Chalk. 1950. Anatomy of the dicotyledons. Vol. II. Oxford Press.

ScotT, D. H. 1923. Studies in fossil botany. Vol. II, Black, Ltd., London.

Skward, A. C., and S. O. Ford. 1906. The Araucarineae recent and extinct. Phil. Trans. Roy. Soc. 198: $305-411$.

South, F.W., and R.H. Compron. 1908. On the anatomy of Dioon edule Lindl. New Phytol. 7:222-229.

Stopes, M. C. 1917. Roots in Bennettites. Ann. Bot. $31: 257-259$.

Thomson, R. B. 1913. On the comparative anatomy and affinities of the Araucarineae. Phil. Trans. Roy. Soc. 204: 1-50. 